\title{
MENINGKATKAN AKTIVITAS BELAJAR PKn SISWA MELALUI \\ PENERAPAN MODEL PEMBELAJARAN TEAM GAMES TOURNAMENT DI KELAS III SD NEGERI 057205 PASAR I
}

\author{
Asriah \\ Guru SD Negeri No. 057205 Pasar I \\ Surel : asriah_s.pd@yahoo.com
}

\begin{abstract}
Improving Student Learning Activities Civic Eduation With Application of Learning Model Team Games Tournament In Class III SD Negeri No. 057205 Pasar I Second Semester T.A 2015/2016. This research aims to improve students' learning activities using Team Games Tournament learning model in class III SD Negeri No. 057205 Pasar I. These research subjects are 27 students. The study lasted for two cycles can be concluded that 1) Activities of student learning through the implementation of the Team Games Tournament learning model is based on observations of the two observers increased from the first cycle to the second cycle. 2) The results of student learning through the implementation of the Team Games Tournament learning model increases from the first cycle to the second cycle.
\end{abstract}

Keywords: Team Games Tournament Learning Model, Student Activities

\begin{abstract}
Abstrak : Meningkatkan Aktivitas Belajar PKn Siswa Melalui Penerapan Model Pembelajaran Team Games Tournament Di Kelas III SD Negeri No. 057205 Pasar I Semester Genap T.A 2015/2016. Penelitian ini bertujuan untuk meningkatkan aktivitas belajar siswa dengan menggunakan model pembelajaran Team Games Tournament di kelas III SD Negeri No. 057205 Pasar I. Subjek penelitian ini berjumlah 27 orang siswa. Penelitian berlangsung selama dua siklus dapat disimpulkan bahwa 1) Aktivitas belajar siswa melalui penerapan model pembelajaran Team Games Tournament berdasarkan pengamatan kedua pengamat mengalami peningkatan dari siklus I ke siklus II. 2) Hasil belajar siswa melalui penerapan model pembelajaran Team Games Tournament meningkat dari siklus I ke siklus II.
\end{abstract}

Kata Kunci: Model Pembelajaran Team Games Tournament, Aktivitas Siswa

\section{PENDAHULUAN}

Pelajaran PKn merupakan pelajaran yang penting karena dipelajari dari tingkat SD sampai SMA. Namun pembelajaran PKn di sekolah sering menghadapi berbagai masalah. Baik dari guru, siswa maupun lingkungan belajar.

Berdasarkan pengalaman mengajar PKn di kelas III SD Negeri No. 057205 Pasar I, masalah yang sering dihadapi antara lain siswa selalu menganggap pelajaran PKn sangat rumit dan sulit dipahami. Siswa juga kurang tertarik dalam memperhatikan penjelasan guru karena model pembelaran yang guru terapkan masih bersifat teacher center, pembelajaran hanya berlangsung satu arah, guru menjelaskan dan siswa hanya mencatat apa yang dijelaskan guru tenpa memahami materi tersebut. Ditambah lagi lingkungan belajar yang kurang mendukung, siswa tidak dimotivasi oleh orang tua untuk mengulang pelajaran dirumah. Sehingga pada saat guru memberikan soal tentang materi yang sudah dijelaskan, siswa sudah tidak mengerti lagi. Waktu yang digunakan menjadi tidak efektif karena guru harus menjelaskan materi yang sama berulangulang. Karena pelajaran PKn yang berkelanjutan ini tidak dapat dilanjutkan apabila siswa belum menguasai materi terdahulu. 
Salah satu upaya yang peneliti lakukan untuk meningkatkan hasil belajar siswa ialah dengan menerapkan model pembelajaran kooperatif. Model pembelajaran ini dipilih untuk meningkatkan motivasi siswa dan melatih kerjasama siswa. Model pembelajaran kooperatif yang dipilih ialah model pembelajaran kooperatif tipe TGT (Team Games Tournament).

Pembelajaran kooperatif model TGT adalah salah satu tipe atau model pembelajaran kooperatif yang mudah diterapkan, melibatkan aktivitas seluruh siswa tanpa harus ada perbedaan status, melibatkan peran siswa sebagai tutor sebaya dan mengandung unsur permainan dan reinforcement. Pada model ini siswa memainkan permainan dengan anggota-anggota tim lain untuk memperoleh tambahan skor pada tim mereka.

Permainan disusun dari pertanyaan-pertanyaan yang relevan dengan pelajaran yang dirancang untuk mengetes pengetahuan yang diperoleh siswa dari penyampaian pelajaran di kelas dan kegiatan-kegiatan kelompok. Permainan ini memungkinkan bagi siswa dari semua tingkat untuk menyumbangkan dengan maksimal bagi skor-skor kelompoknya. Aktivitas belajar dengan permainan yang dirancang dalam pembelajaran kooperatif model TGT memungkinkan siswa dapat belajar lebih rileks disamping menumbuhkan tanggung jawab, kerjasama, persaingan sehat dan keterlibatan belajar.

Berdasarkan latar belakang di atas, maka dapat dirumuskan suatu masalah sebagai berikut; 1) Apakah terjadi peningkatan aktivitas belajar PKn siswa melalui model pembelajaran TGT (Team Games Tournament) di kelas III SD Negeri No. 057205 Pasar I T.A.
2015/2016?; 2) Apakah terjadi peningkatan hasil belajar PKn siswa melalui model pembelajaran TGT (Team Games Tournament) di kelas III SD Negeri No. 057205 Pasar I T.A. 2015/2016?

Sesuai dengan permasalahan di atas, penelitian ini bertujuan untuk; 1) Untuk mengetahui peningkatan aktivitas belajar PKn siswa melalui model pembelajaran TGT (Team Games Tournament) di kelas III SD Negeri No. 057205 Pasar I T.A. 2015/2016; 2). Untuk mengetahui peningkatan hasil belajar PKn siswa melalui model pembelajaran TGT (Team Games Tournament) di kelas III SD Negeri No. 057205 Pasar I T.A. 2015/2016.

Djamarah dan Zain (2006) mengatakan bahwa belajar adalah proses perubahan perilaku berkat pengalaman dan latihan. Artinya, tujuan kegiatan adalah perubahan tingkah laku, baik yang menyangkut pengetahuan, keterampilan maupun sikap; bahkan meliputi segenap aspek organisme atau pribadi. Jadi, hakikat belajar adalah perubahan.

Slavin dalam Isjoni (2009:15) mengemukakan bahwa "Pembelajaran kooperatif adalah suatu model pembelajaran dimana sistem belajar dan bekerja dalam kelompok-kelompok kecil yang berjumlah 4-6 orang secara kolaboratif sehingga dapat merangsang siswa lebih bergairah dalam belajar".

\section{METODE}

Lokasi penelitian ini adalah SD Negeri No. 057205 Pasar I, yang beralamat di Jalan Pasar I Stabat Lama. Materi Pembelajaran yang diterapkan selama pengambilan data adalah Harga Diri. Waktu penelitian ini dilaksanakan pada semester genap tahun ajaran 2015/2016 selama 5 (empat) bulan 
mulai dari bulan Februari sampai dengan Juni 2015. Pengambilan data dilaksanakan pada bulan April selama 4 (empat) KBM yang dibagi dalam 2 (dua) Siklus.

Subjek dalam penelitian ini sebanyak I (satu) kelas yaitu kelas III SD Negeri No. 057205 Pasar I. Banyak subjek penelitian yakni 27 orang siswa

Alat pengumpul data dalam penelitian ini adalah; 1) tes hasil belajar; 2) lembar observasi aktivitas siswa;

Penelitian ini menggunakan Penelitian Tindakan Kelas (PTK). PTK adalah suatu bentuk kajian yang bersifat reflektif oleh pelaku tindakan yang dilakukan untuk meningkatkan kemantapan rasional dari tindakan mereka dalam melaksanakan tugas, memperdalam pemahaman terhadap tindakan-tindakan yang dilakukan itu, serta memperbaiki kondisi dimana praktek pembelajaran tersebut dilakukan.

Sesuai dengan jenis penelitian yang dipilih, yaitu penelitian tindakan kelas, maka penelitian ini menggunakan model penelitian tindakan dari Kemmis dan Taggart (dalam Sani dan Sudiran, 2012), yaitu berbentuk spiral dari siklus yang satu ke siklus yang berikutnya. Setiap siklus meliputi planning (rencana), action (tindakan), observation (pengamatan), dan reflection (refleksi). Langkah pada siklus berikutnya adalah perencanaan yang sudah direvisi, tindakan, pengamatan, dan refleksi.

Metode Analisis Data pada penelitian ini digunakan metode deskriptif dengan membandingkan hasil belajar siswa sebelum tindakan dengan hasil belajar siswa setelah tindakan.

Langkah-langkah pengolahan data sebagai berikut:
1. Merekapitulasi nilai pretes sebelum tindakan dan nilai tes akhir Siklus I dan Siklus II

2. Menghitung nilai rerata atau persentase hasil belajar siswa sebelum dilakukan tindakan dengan hasil belajar setelah dilakukan tindakan pada Siklus I dan Siklus II untuk mengetahui adanya peningkatan hasil belajar.

Indikator keberhasilan guru dalam penelitian ini adalah peningkatan hasil belajar siswa dalam belajar yang diajar dengan model pembelajaran kooperatif tipe TGT. Dimana indikator yang diterapkan dalam penelitian ini adalah ketuntasan klasikal $85 \%$ dari jumlah siswa sampel melampaui nilai KKM yang diterapkan di sekolah. Ini berarti bila jumlah siswa kelas III yang memperoleh nilai ketuntasan di atas KKM adalah $85 \%$ dari jumlah siswa seluruhnya maka penelitian ini dianggap berhasil.

\section{PEMBAHASAN}

Data penelitian ini diambil dari tes hasil belajar siswa dan observasi aktivitas belajar siswa. Tes hasil belajar siswa digunakan untuk melihat kemampuan siswa dalam memahami materi dalam mata pelajaran matematika. Sedangkan observasi aktivitas siswa digunakan untuk melihat aktivitas siswa selama menerapkan model pembeajaran kooperatit tipe TGT. Penelitian ini dilakukan selama dua siklus, dan setiap siklus terdiri dari dua pertemuan.

Sebelum melaksanakan kegiatan belajar mengajar, peneliti memberikan pretes kepada siswa untuk melihat kemampuan awal siswa sebelum menerapkan model pembelajaran kooperatif tipe TGT. Nilai rata-rata siswa pada pretes sebesar 50,4 dan tak 
seorang siswa pun mendapat nilai diatas KKM. Hal ini menunjukkan kesiapan siswa yang kurang pada saat memulai pembelajaran

Observasi menghasilkan data aktivitas belajar siswa yang belum begitu menunjukkan siswa aktif diskusi. Data hasil observasi aktivitas belajar siswa disajikan dalam Tabel.

\section{Tabel Skor Aktivitas Belajar Siswa} Siklus I

\begin{tabular}{|c|c|c|c|}
\hline No & Aktivitas & Skor & Proporsi \\
\hline 1 & $\begin{array}{l}\text { Menulis, } \\
\text { membaca }\end{array}$ & 23 & $38 \%$ \\
\hline 2 & $\begin{array}{l}\text { Mengerjakan } \\
\text { LKS }\end{array}$ & 19 & $32 \%$ \\
\hline 3 & $\begin{array}{l}\text { Bertanya pada } \\
\text { teman }\end{array}$ & 12 & $19 \%$ \\
\hline 4 & $\begin{array}{l}\text { Bertanya pada } \\
\text { guru }\end{array}$ & 4 & $6 \%$ \\
\hline 5 & $\begin{array}{l}\text { Yang tidak } \\
\text { relevan }\end{array}$ & 3 & $5 \%$ \\
\hline & Jumlah & 60 & $100 \%$ \\
\hline
\end{tabular}

Merujuk pada Tabel aktivitas dominan yang dilakukan siswa adalah menulis dan membaca (38\%) kondisi ini belum sesuai dengan yang diharapkan karena seharusnya aktivitas diskusi lebih dominan ketimbang aktivitas individual tersebut, sementara aktivitasi mengerjakan LKS dalam posisi kedua $(32 \%)$, bertanya pada guru $(6 \%)$ atau siswa masih sangat bergantung pada guru. Dan aktivitas bertanya pada teman dan yang tidak relevan berturut-turut (19\%) dan (5\%).

Pada akhir proses belajar mengajar siswa diberi tes Formatif I dengan tujuan untuk mengetahui tingkat keberhasilan siswa dalam proses belajar mengajar yang telah dilakukan. Adapun data hasil formatif pada Siklus I ditunjukkan Tabel.
Tabel Distribusi Hasil Formatif 1

\begin{tabular}{|c|c|c|}
\hline Nilai & Frekunsi & Rata-rata \\
\hline 60 & 10 & \multirow{2}{*}{77.8} \\
\cline { 1 - 2 } 80 & 10 & \multirow{2}{*}{7} \\
\cline { 1 - 2 } 100 & 7 & \\
\cline { 1 - 2 } Jumlah & 27 & \\
\hline
\end{tabular}

Merujuk pada Tabel tersebut, nilai terendah Formatif I adalah 60 dan tertinggi adalah 100. Merujuk pada KKM sebesar 65 maka hanya 17 dari 27 orang siswa mendapat nilai ketuntasan atau ketuntasan klasikal tercapai sebesar $63 \%$. Nilai ini berada di bawah kriteria ketuntasan klasikal sebesar 85\% sehingga dapat dikatakan KBM Siklus I gagal memberi ketuntasan belajar dalam kelas. Nilai rata-rata kelas adalah 77.8 masih di bawah KKM. Dengan demikian maka peneliti berusaha melakukan tindakan perbaikan dalam melaksanakan pembelajaran Siklus II yang dirasa perlu.

Pada tahap ini akan dikaji apa yang telah terlaksana dengan baik maupun yang masih kurang baik dalam proses belajar mengajar dengan penerapan model kooperatif tipe Teams Games Tournament (TGT). Diakhir KBM Siklus I peneliti mendapati informasi dari pengamatan, diantaranya:

1. Siswa masih banyak yang bermainmain dalam diskusi kelompok.

2. Masih banyak siswa yang belum memahami perannya dalam kelompok

3. Masih ada siswa yang kurang serius dalam belajar.

4. Masih banyak siswa yang kurang percaya diri sehingga mereka malu/takut membacakan hasil diskusinya di depan kelas.

5. Hasil belajar siswa pada siklus I belum mencapai ketuntasan meskipun terlihat ada perubahan hasil belajar siswa yang cukup 
signifikan. Untuk lebih jelasnya mengenai keberhasilan dan kelemahan yang terdapat dalam KBM siklus I dapat dilihat pada tabel dibawah ini.

Observasi yang dilakukan dua guru sejawat menghasilkan data aktivitas belajar siswa Siklus II yang mengalami perbaikan dibandingkan Siklus sebelumnya. Data hasil observasi aktivitas belajar siswa disajikan dalam Tabel.

Tabel Skor Aktivitas Belajar Siswa Siklus II

\begin{tabular}{|c|c|c|c|}
\hline No & Aktivitas & Skor & Proporsi \\
\hline 1 & $\begin{array}{l}\text { Menulis, } \\
\text { membaca }\end{array}$ & 16 & $32 \%$ \\
\hline 2 & Mengerjakan LKS & 21 & $41 \%$ \\
\hline 3 & $\begin{array}{l}\text { Bertanya pada } \\
\text { teman }\end{array}$ & 9 & $18 \%$ \\
\hline 4 & Bertanya pada guru & 3 & $5 \%$ \\
\hline 5 & Yang tidak relevan & 2 & $4 \%$ \\
\hline & Jumlah & 50 & $100 \%$ \\
\hline
\end{tabular}

Merujuk pada Tabel aktivitas dominan yang dilakukan siswa adalah mengerjakan LKS (41\%) kondisi ini telah sesuai dengan yang diharapkan karena seharusnya aktivitas kerja memang lebih dominan ketimbang aktivitas individual menulis dan membaca yang berada pada peringkat kedua (32\%), bertanya pada guru turun menjadi $(5 \%)$ atau siswa mulai mandiri. Hal ini diperkuat dengan aktivitas bertanya pada teman dan yang tidak relevan berturut-turut (18\%) dan (4\%).

Pada akhir proses belajar mengajar Siklus II siswa diberi tes Formatif II dengan tujuan untuk mengetahui tingkat keberhasilan siswa dalam proses belajar mengajar yang telah dilakukan. Adapun data hasil formatif pada Siklus II ditunjukkan Tabel.
Tabel Distribusi Hasil Formatif II

\begin{tabular}{|c|c|c|}
\hline Nilai & Frekunsi & Rata-rata \\
\hline 60 & 3 & \multirow{2}{*}{86.7} \\
\cline { 1 - 2 } 80 & 12 & \\
\cline { 1 - 2 } 100 & 12 & \\
\cline { 1 - 2 } Jumlah & 27 & \\
\hline
\end{tabular}

Merujuk pada Tabel tersebut nilai terendah Formatif II adalah 60 dan tertinggi adalah 100. Merujuk pada KKM sebesar 65 maka 24 dari 27 orang siswa mendapat nilai ketuntasan atau ketuntasan klasikal tercapai sebesar $88 \%$. Nilai ini berada di atas kriteria ketuntasan klasikal sebesar $85 \%$ sehingga dapat dikatakan KBM Siklus II berhasil memberi ketuntasan belajar dalam kelas. Nilai rata-rata kelas adalah 86.7 telah mencapai KKM. Dengan demikian maka penelitian telah berhasil memberi ketuntasan klasikal dalam dua siklus.

Pada tahap ini akan dikaji apa yang telah terlaksana dengan baik maupun yang masih kurang baik dalam proses belajar mengajar dengan penerapan model kooperatif tipe TGT. Dari data-data yang telah diperoleh dapat di uraikan sebagai berikut:

1. Selama proses belajar mengajar guru telah melaksanakan semua pembelajaran dengan baik. Meskipun ada beberapa aspek yang belum sempurna, tetapi persentase pelaksanaannya untuk masingmasing aspek cukup besar.

2. Berdasarkan data hasil pengamatan diketahui bahwa siswa aktif selama proses belajar berlangsung.

3. Kekurangan pada siklus sebelumnya sudah mengalami perbaikan dan peningkatan sehingga menjadi lebih baik.

4. Hasil belajar siswa pada siklus II mencapai ketuntasan. 
Model kooperatif tipe TGT memiliki dampak positif dalam meningkatkan hasil belajar siswa. Hal ini dapat dilihat pada gambar 4.2, semakin mantapnya pemahaman dan penguasaan siswa terhadap materi yang telah disampaikan guru selama ini (ketuntasan belajar meningkat dari sklus I, dan II) yaitu masing-masing 63\% dan $88 \%$. Pada siklus II ketuntasan belajar siswa secara klasikal telah tercapai. Ini berarti tiap siklusnya terjadi peningkatan hasil belajar penerapan model kooperatif tipe Teams Games Tournament (TGT) terhadap hasil belajar siswa.

Merujuk pada gambar 4.2, aktivitas siswa juga tampak terlihat ada perubahan yang positif ditinjau dari semakin sedikitnya proporsi aktivitas yang tidak relevan. Berdasarkan analisis data, diperoleh aktivitas siswa dalam proses pembelajaran PKn dengan model kooperatif tipe TGT yang paling dominan adalah mengerjakan LKS, mendengarkan/memperhatikan

penjelasan guru, dan diskusi antar siswa/antara siswa dengan guru. Jadi dapat dikatakan bahwa aktivitas siswa dapat dikategorikan aktif. Hal ini terlihat dari semakin berkurangnya aktivitas yang tidak releven dari 5\% menjadi hanya $4 \%$. Ini berarti pembelajaran berlangsung lebih efektif pada siklus II. Aktivitas membaca/menulis pada siklus I adalah 38\% dan naik menjadi $32 \%$ pada siklus II. Aktivitas bekerja naik dari $32 \%$ pada siklus I menjadi $41 \%$ pada siklus II. Ini berarti siswa sudah mulai mengerti akan perannya dalam kelompok dan sudah mulai terbiasa dengan model pembelajaran yang diterapkan. Aktivitas bertanya kepada teman $19 \%$ pada siklus I menurun menjadi $18 \%$ pada siklus II. Ini berarti siswa sudah terbiasa dengan model yang digunakan sehingga siswa menjadi lebih aktif di dalam diskusi. Aktivitas bertanya kepada guru mengalami menurun dari sebelumnya 5\% aktivitas aktif pada siklus I menjadi $6 \%$ pada siklus II. Ini berarti model kooperatif tipe TGT telah memberikan dampak yang positif dalam proses pembelajaran di sekolah.

\section{KESIMPULAN}

Adapun kesimpulan dari upaya meningkatkan hasil belajar kognitif siswa melalui model pembelajaran TGT pada mata pelajaran PKn di kelas III SD Negeri No. 057205 Pasar I sebagai berikut:

1. Hasil belajar siswa melalui model pembelajaran kooperatif tipe TGT dalam mata pelajaran PKn pada siklus I dengan rata-rata 77,8 dengan ketuntasan klasikal $63 \%$ dan siklus II dengan rata-rata 86,7 dengan ketuntasan klasikal $88 \%$. Dengan demikian terjadi peningkatan hasil belajar siswa dan ketuntasan yang diharapkan tercapai pada mata pelajaran PKn di kelas III SD Negeri No. 057205 Pasar I T.A. 2015/2016.

2. Aktivitas belajar siswa pada siklus I antara lain aktivitas menulis 38\%, mengerjakan LKS $32 \%$, bertanya pada teman $19 \%$, bertanya pada guru $6 \%$, sedangkan aktivitas yang tidak relevan dengan KBM 5\%, sedangkan Aktivitas belajar siswa pada siklus II antara lain aktivitas menulis 32\%, mengerjakan LKS $41 \%$, bertanya pada teman $18 \%$, bertanya pada guru $5 \%$, sedangkan aktivitas yang tidak relevan dengan KBM 4\% Dengan demikian terjadi peningkatan aktivitas belajar siswa pada mata pelajaran PKn melaui model pembelajaran TGT di kelas 
III SD Negeri No. 057205 Pasar I

T.A. 2015/2016.

\section{DAFTAR RUJUKAN}

Asriah. (2016). Penerapan Model Pembelajaran Team Game

Tournament Dalam

Meningkatkan Hasil Belajar Siswa Di Kelas III SD Negeri No. 057205 Pasar I Semester Genap T.A 2015/2016. (PTK Karangan Sendiri).

Djamarah, S dan Zain, A. (2006). Strategi Belajar Mengajar. Jakarta: Rineka Cipta.

Isjoni, (2009). Cooperative Learning. Bandung: Penerbit Alfabeta.

Sani, R.A. dan Sudiran, (2012), Meningkatkan Profesionalisme Guru Melalui Penelitian Tindakan Kelas, Citapustaka Media Perintis, Bandung.

Sanjaya, W., (2009), Strategi Pembelajaran Berorientasi Standar Proses Pendidikan, Penerbit Kencana, Jakarta.

Slamet, Tijan dkk.(2008). Buku Pendidikan Kewarganegaraan Untuk SD/MI Kelas III. Pusat Perbukuan, Departemen Pendidikan Nasional. Jakarta.

Sudjana, (2005), Metode Statistika, Penerbit Bumi Aksara, Jakarta. 